ters have become two a penny. That is why Mr Heseltine's supporters should tell him that while his heart is in the right place, his head is in the clouds; that battling for a united Europe with Westland Helicopters as a slogan is fruitless. Mr Heseltine's local difficulty is that his supporters are not, like him, Europeans by instinct but rather xenophobes. He will not be the first to find himself caught out like that.

\section{No more numbers game}

Last week's Soviet arms control proposals are the best yet, perhaps the best for forty years.

WASHINGTON is still forgivably hesitant and uncertain about last week's proposals on strategic arms control, which are breathtaking in their radicalism. Such a break with the recent past is bound to catch people off guard, which is as it should be. But it would be a great mistake to write off Mr Mikhail Gorbachev's suggestions for what should happen next at Geneva as yet another proposal which, when picked apart, will be found to contain little of substance, or be otherwise objectionable. For the novelty in what Mr Gorbachev had to say last week is his explicit acknowledgement that substantial controls on strategic weapons will not be reached quickly, and that it may take until the end of the century for the abolition of nuclear weapons to be feasible. Previous Soviet leaders have so often impeded rational discussion with impatient demands for "general and comprehensive disarmament" the day after tomorrow that the influence of a pragmatist should be generally welcomed.

The further merit of the Gorbachev plan, with several independent components such as the withdrawal of Soviet and US missiles from the European theatre, a reduction by a half of strategic arms and so on, is that the scheme is plainly not meant as a package but as a negotiating framework. If it is the will of the superpowers to reduce the numbers of strategic weapons they deploy against each other, for their mutual benefit and that of bystanders, it is clear that progress can be made only step by step, and that the first steps must be taken before even the character of later steps is known. The trick is to ensure that none of the intermediate steps will be obstacles to those certain to follow. The negotiators at Geneva are hardly in a position to take such a grand view, which is why there is a need for a response from none other than President Reagan himself.

There are two snags, of which the first is the obvious danger that the future ideal may undermine what is feasible now. It is clearly essential that the goal of abolishing nuclear weapons by the end of the century should not distract attention from tangible steps that could be taken now. The Geneva negotiators who reassembled last week could do worse than settle for a tidying up of the agreements to which they are already parties, SALT II and the Anti-Ballistic Missile Treaty in particular (see Nature 319,$164 ; 1986$ ), which would seem far from an empty achievement if there is a firm promise of better things to come.

But does the world, or anybody, wish to see the back of nuclear weapons altogether? That is the second snag that everybody must face. The immediate reaction to the Gorbachev proposals from Mr Zbigniew Brzezinski, President Carter's National Security Advisor, that the scheme is a recipe to "make the world safe for conventional war", points to the nub of the difficulty. Nuclear weapons have become so much an aid to the preservation of the status quo that even the most farsighted statesmen will think twice before suggesting their abolition. Only the most idealistic or naive believe that the abolition of nuclear weapons could be finally accomplished without agreement on the uses to which conventional forces would be put. But issues like that even touch the degree to which national sovereignty is an autonomous force in international relations. Perhaps it is not too soon to begin asking questions like these, but their difficulty should warn even the optimists that Mr Gorbachev's timetable, worthy though it is, will be much delayed.

\section{Scribes in space}

The US government plans to put a journalist in space later in the year. Is it wise?

SOME years ago, US journalism was enlived by a stocky character with a Brooklyn accent whose career had been transformed by a single assignment, that of being the first journalist to witness in that capacity the explosion of a nuclear weapon at a Pacific atoll. William L. Lawrence by birth, he was known to everybody as "Atomic Bill", and required by the expectations of his companions and editors to fill the role, whatever his inclinations may have been. For decades afterwards, no nuclear reactor could go critical, no diplomatic conference on the future of nuclear energy could take place, without his presence. Only when he retired from the New York Times to a Mediterranean island was Atomic Bill able to follow his chief interest, pre-nucleic acid biochemistry. But now, with characteristic indifference to the lessons of history, the National Aeronautics and Space Administration (NASA) is about to wish a similar fate on another unsuspecting journalist, the first ever to be sent up by shuttle.

By the closing date for applications last Thursday, the US Association of Schools of Journalism and Mass Communication, rising to the only occasion in its history likely to be remembered generally, was said to be swimming in a large proportion of the 4,000 application forms requested by aspiring Orbit Micks (or Megs, as the case may be), many of them turned in, in the best traditions, right on deadline. It is hoped that not too many readers will cancel their subscriptions because none of the members of Nature's staff who satisfies the condition of being a US citizen will also meet the requirement of having been in journalism for five years. But there are more onerous conditions.

The worst is that the unlucky winner of the competition will have to work as a one-person "pool", a kind of communal resource to be exploited by all his or her natural competitors, who will be free to demand answers to whatever questions come into their heads. ("Say, that nausea, is it worse when you move about?") With NASA in charge of all communications, the pool reporter's traditional ingenuity in keeping the best scraps of information for his own employers will be fully tested. NASA's demand that the reporter should "not intrude on the private lives" of his companions "without their express permission" will not easily be satisfied. It will be irksome that personal equipment that cannot be "flight-qualified" will have to be replaced by what NASA thinks best. The summer in Houston is not everybody's idea of bliss.

Who will be chosen? This is where the fun will start. The medical examination seems not much of a hurdle. The need for a security clearance may be a more serious obstacle even though NASA promises that recruitment will not be based on "political associations or beliefs". But the real fun starts with the two "essay questions" that applicants must answer. One whole sheet of blank paper awaits the response to "How will you attempt to fulfill" the purpose of communicating the "unique experience of space travel"? Maybe the selection panels, representing as they do the schools of journalism and mass communication, have ways of telling when people who fill this sheet with phrases like "mankind liberated from tedious Earth" will lapse, in the event, into phrases like "I can see Paris, France!" But the trick question is the second, which asks that the chosen journalist should speculate, "looking 10 or 20 years into the future", about the value to journalism of the facility "to report regularly from space". It is as if a restaurant were to offer free dinners to those with interesting opinions on the value of dining out. Cruelly, NASA retains the right to publish these essay questions, ensuring that it can ruin not just the career of its equivalent of Atomic Bill, but all those who answer this question with a straight face. 